Contributions:

A Study design/planning

B Data collection/entry

C Data analysis/statistic

D Data interpretation

E Preparation of manuscript

F Literature analysis/search

$\mathrm{G}$ Funds collection

\title{
BENIGN PAROXYSMAL POSITIONAL VERTIGO (BPPV): CASE REPORT WITH EPLEY MANOEUVER
}

\author{
Ana Rita Silva ${ }^{1 A B D E F}$, David Tome ${ }^{1 B C D}$, Unn Siri Olsen ${ }^{2 E F}$ \\ ${ }^{1}$ Department of Audiology, Laboratory of Audiology, Superior School of Health, \\ Polytechnic Institute of Porto, Porto, Portugal \\ ${ }^{2}$ Department of Pharmacy, Faculty of Health, North University, Bodo, Norway
}

Corresponding author: David Tome, Department of Audiology, Laboratory of Audiology, Superior School of Health, Polytechnic Institute of Porto, Porto, Portugal,

e-mail: dts@eu.ipp.pt

\begin{abstract}
Background: Benign paroxysmal positional vertigo (BPPV) is a peripheral vestibular dysfunction which represents about $70 \%$ of vestibular pathology presented at ENT clinics. However, a variety of first treatment approaches are reported among clinicians.

Case report: We present the case of a 39-year-old woman who presented vertigo which worsened with head movement to the left. The patient reported dizziness and migraine over the previous three days. Audiological testing revealed normal hearing, but under postural examination the Dix-Hallpike manoeuver was positive to BPPV of the left posterior canal. The patient was treated with a single Epley manoeuver.
\end{abstract}

Conclusions: After the Epley manoeuver the patient had no further symptoms of vertigo or dizziness. The Dix-Hallpike manoeuver was effective as a differential diagnosis. The Epley manoeuver was successful in a case in which canalithiasis was believed to be the cause of the vertigo. Key words: dizziness $\bullet$ rehabilitation $\bullet$ semicircular canals $\bullet$ vestibular disease

\section{EL VERTIGO POSTURAL PAROXÍSTICO BENIGNO (BPPV): ESTUDIO DEL CASO DE LA MANIOBRA DE EPLEY}

\section{Resumen}

Introducción: El vértigo postural paroxístico benigno (inglés: benign paroxysmal positional vertigo, BPPV) es una disfunción de la porción periférica del sistema vestibular, la cual constituye un $70 \%$ de los trastornos vestibulares observados en clínicas otorrinolaringológicas. Los clinicistas describen sin embargo varios enfoques distintos con respecto a su tratamiento temprano.

Estudio del caso: En el presente trabajo se presenta el caso de una mujer de 39 años con síntomas de vértigo que se intensificaban al mover la cabeza hacia el lado izquierdo. La paciente se quejaba de una sensación subjetiva de mareo y migrañas durante tres días previos a la consulta. Las pruebas audiológicas demostraron una audición normal, sin embargo el test de pruebas posturales demostró la maniobra de DixHallpike positiva, lo cual confirmó el vértigo postural benigno del canal semivestibular posterior del lado izquierdo. La paciente fue curada con una maniobra única de Epley.

Conclusiones: Tras aplicar la maniobra de Epley, en la paciente no se observaban más síntomas de vértigo o sensaciones de mareo. La maniobra de Dix-Hallpike proporciona un diagnóstico diferencial eficaz en casos donde como la causa del vértigo se indica el fenómeno de canalolithiasis.

Palabras clave: sensación subjetiva de mareo • rehabilitación • canales semicirculares • trastorno vestibular

\section{ДОБРОКАЧЕСТВЕННОЕ ПАРОКСИЗМАЛЬНОЕ ПОЗИЦИОННОЕ ГОЛОВОКРУЖЕНИЕ (ДППГ): ОПИСАНИЕ СЛУЧАЯ ПРИЕМА ЭПЛИ}

\section{Изложение}

Введение: Доброкачественное пароксизмальное позиционное головокружение (англ. benign paroxysmal positional vertigo, $\mathrm{BPPV)} \mathrm{является} \mathrm{дисфункцией} \mathrm{периферического} \mathrm{отдела} \mathrm{вестибулярной} \mathrm{системы,} \mathrm{к} \mathrm{которым} \mathrm{относится} \mathrm{около} \mathrm{70 \%} \mathrm{вестибуляр-}$ ных расстройств, наблюдаемых в отоларингологических клиниках. Однако клиницисты описывают множество различных подходов к начальному лечению.

Описание случая: В настоящей работе представлен случай 39-летней женщины с симптомами головокружения, которые усиливались при наклоне головы в левую сторону. Пациентка сообщала о субъективных ощущениях вращения предметов и мигрени 
в течение трех дней, предшествовавших консультации. Аудиологические исследования показали отсутствие нарушений слуха, однако исследование позиционных тестов показало положительную пробу Проба Дикса-Холлпайка, подтвердив ДППГ заднего полукружного канала с левой стороны. Пациентка была вылечена с помощью однократного использования приема Эпли.

Выводы: После применения приема Эпли у пациентки не наблюдались дальнейшие симптомы головокружений или ощущение вращения предметов. Проба Дикса-Холлпайка обеспечила эффективную дифференциальную диагностику в том случае, когда причиной головокружений считалось явление каналолитиаза.

Ключевые слова: субъективное ощущение вращения предметов • реабилитация • полукружные каналы • вестибулярные расстройства

\section{ŁAGODNE POŁOŻENIOWE ZAWROTY GŁOWY (BPPV): OPIS PRZYPADKU MANEWRU EPLEYA}

\section{Streszczenie}

Wstęp: Łagodne położeniowe zawroty głowy (ang. benign paroxysmal positional vertigo, BPPV) jest dysfunkcją części obwodowej układu przedsionkowego, która stanowi około $70 \%$ zaburzeń przedsionkowych, obserwowanych w klinikach otorynolaryngologicznych. Wśród klinicystów jednak opisywanych jest wiele różnych podejść do początkowego leczenia.

Opis przypadku: W niniejszej pracy zaprezentowano przypadek 39-letniej kobiety z objawami zawrotów głowy, które wzmagały się przy poruszaniu głową w lewą stronę. Pacjentka zgłaszała subiektywne odczucie wirowania i migrenę w ciągu trzech dni poprzedzających konsultację. Badania audiologiczne wykazały słuch prawidłowy, jednak badanie prób posturalnych pokazało pozytywny manewr Dix-Hallpike’a, potwierdzając BPPV kanału półkolistego tylnego po lewej stronie. Pacjentkę wyleczono jednorazowym manewrem Epleya.

Wnioski: Po zastosowaniu manewru Epleya u pacjenta nie stwierdzono dalszych objawów zawrotów głowy lub uczucia wirowania. Manewr Dix-Hallpike’a zapewnił efektywną diagnostykę różnicową w przypadku, gdy za przyczynę zawrotów głowy uznawano zjawisko canalolithiasis. Słowa kluczowe: subiektywne odczucie wirowania $\bullet$ rehabilitacja $\bullet$ kanały półkoliste $\bullet$ zaburzenie przedsionkowe

\section{Background}

Benign paroxysmal positional vertigo (BPPV) is a peripheral vestibular dysfunction, first described by Barany in 1921 [1].

The physiopathology of this dysfunction is characterized by migration of otoconia in the semicircular canals, most commonly the posterior semicircular canal. There are two theories that try to explain this migration and its impact: cupulolithiasis and canalithiasis. Cupulolithiasis was described by Schuknecht in 1969 [2]; here otoconia are said to be deposited in the cupula of the affected semicircular canal, and gravity initiates a stimulus which the nervous system interprets as head rotation and therefore as movement. Canalithiasis was the explanation given by Hall in 1979 , and is the more commonly accepted explanation [3,4]; here otoconia are said to be released from the utricular macula, suspended in the endolymph, and erroneously stimulate the ampulla of the pathologic semicircular canal [5].

BPPV patients report symptoms such as rotational vertigo of short duration and high intensity, and rotatory nystagmus in the plane of the affected semicircular canal, with the rapid phase directed to the pathologic side [5]. The symptoms have their origin in fast head movements. In the orthostatic position, sudden movements can cause vertigo. The results are rotational, horizontal, or vertical nystagmus at the same time as vertigo. In $60 \%$ of patients vestibular exams give normal results [6]. Caloric tests of the pathologic hear reveal vestibular unilateral hyporeflexia. Posturography reveals an increased instability which is aggravated by a visual afferent decrease.

In diagnosing BVVP, the most effective test is the DixHallpike manoeuver, which tries to reproduce the vertigo sensation [7]. The Dix-Hallpike manoeuver induces vertigo and dizziness in patients with BPPV, and provides differential diagnosis $[7,8]$.

A positive result indicates pathology of the posterior canal. During the manoeuver, we can verify the presence of a geotropic horizontal-rotational nystagmus of short duration, which is subject to habituation and accompanied by dizziness and vertigo [5].

Treatment for BPPV is vestibular rehabilitation by applying repositioning manoeuvers or vestibular habituation manoeuvers (such as the Brandt and Daroff manoeuver) [9]. The main goal is to reposition otoconia back to their point of origin, the utricular macula. Manoeuvers specific to the posterior canal are the Harvey, Semont, Toupet, Epley, and Herdman manoeuvers; there are also the vestibular habituation exercises of Norré and the vestibular exercises of Fujini et al. $[5,8,10]$.

The Epley manoeuver is used in BPPV cases in order to induce the otoconia to reposition to the maculas. In this procedure, the patient is advised to take their vertigo medication on the day before the rehabilitation session. During the exam, ultrasound or a bone vibrator is used to promote otoconia migration $[8,10,11]$.

At the end of the treatment we have to verify whether the rehabilitation has been effective or whether the vertigo and dizziness remain.

\section{Case report}

At the first appointment the patient (female, 39 years) complained of vertigo over the previous 3 days, with severe aggravation with head movements to the left. Vertigo 
lasted 1 minute and provoked migraine. The patient did not complain of hearing fluctuation or tinnitus. Otoscopy and tympanometry were normal. In acumetry, a $256 \mathrm{~Hz}$ Rinne was positive bilaterally; there was no lateralization in the Weber test.

Pure tone audiometry revealed normal hearing [12]. Speech audiometry revealed a SRT of $10 \mathrm{~dB}$ HL with $100 \%$ discrimination in both ears.

The Romberg and Unterberger tests revealed positivity of peripheral vestibulopathy for the left side. During the postural examination the Dix-Hallpike manoeuver was executed. The patient mentioned dizziness and nausea, and there was a geotropic horizontal-rotational nystagmus. This exam revealed BPPV of the left posterior canal.

One single Epley manoeuver was applied, and further positional exercises at home were recommended.

At the second appointment one month later, the patient reported no vertigo or dizziness. The patient reported intermittent tinnitus. Pure-tone and speech audiometry were normal, as before. The Dix-Hallpike manoeuver was negative to BPPV. We recommended a re-evaluation one month later.

\section{Discussion}

BPPV is one of the main causes of vertigo. The manoeuver that is most effective in diagnosing the condition is the Dix-Hallpike manoeuver [6,7]. When a positive response is elicited, there are several manoeuvers that can help rehabilitate the patient.

We verified that one Epley manoeuver was enough for the patient to start feeling better, suppressing dizziness and vertigo symptoms $[13,14]$. As a number of studies report, one Epley manoeuver is effective in $47 \%$ of cases [9]. Thus, an Epley manoeuver should always be the first repositioning manoeuver performed, particularly because it is comfortable for the patient. On the other hand, if the manoeuver is not effective we recommend a more complete evaluation, using exams such as the caloric test and the video head impulse test (vHIT). Alternatively, any posturography protocol can be used as a complementary exam in order to provide a prognosis [15].

In this reported case, the origin of the BPPV was taken to be abnormal stimulation of the ampulla cupulas caused by otoconia suspended in the endolymph of the left posterior canal. A successful way of rehabilitating the patient was with an Epley manoeuver involving head movement. Canalithiasis explains the BPPV symptoms and their characteristics (such as short duration and latency and fatigability). Patients whose BPPV is due to this condition have good results with the Epley's treatment, with rehabilitation rates between 87 and 100\% [11,16-19].

\section{Conclusions}

This case study shows that a simple Epley maneuver was sufficient to treat posterior canal BPPV, and other posterior canal repositioning maneuvers were not required.

\section{References:}

1. Barany R, Dix MR, Hallpike CS. The pathology, symptomatology and diagnosis of certain common disorders of the vestibular system. Proc Royal Soc Med, 1921; 45: 341-54.

2. Schuknecht HF. Cupulolithiasis. Arch Otolaryngol, 1969; 90: 113-26.

3. Hall SF, Rudy R, McClure JA. The mechanics of benign paroxysmal positional vertigo. J Otolaryngol, 1979; 8: 151-58.

4. Bhattacharyya N, Baugh RF, Orvidas L, Barrs D, Bronston L, Cass $\mathrm{S}$ et al. Clinical practice guideline: benign paroxysmal positional vertigo. Otolaryngol-Head Neck Surg, 2008; 139 (5 Suppl. 4): S47-81.

5. Macedo A. [Abordagem da sindrome vertiginoso.] Acta Med Port, 2010; 23(1): 95-100 [in Portuguese].

6. Portmann C, Michel P. [Précis D’Audiométrie Clinique.] 6a Edição: Masson; 1998 [in Portuguese].

7. Dix MR, Hallpike CS. The pathology, symptomatology and diagnosis of certain common disorders of the vestibular system. Proc Royal Soc Med, 1952; 45: 341-54.

8. Parnes LS, Agrawal SK, Atlas J. Diagnosis and management of benign paroxysmal positional vertigo (BPPV). CMAJ, 2003; 169(7): 681-93.

9. Maia RA, Diniz FL, Carlesse A. Treatment of benign paroxysmal positional vertigo with repositioning manoeuvers. Rev Bras ORL, 2001; 67(5): 612-16.

10. Helminski JO, Zee DS, Janssen I, Hain TC. Effectivenss of particle repositioning maneuvers in the treatment of benign paroxysmal positional vertigo: A systematic review. Phys Ther, 2010; 90(5): 663-78.
11. Epley JM. The canalith repositioning procedure for treatment of benign paroxysmal positional vertigo. Otolaryngol Head Neck Surg, 1992; 107: 399-404.

12. Bureau International D’Audiophonologie. Audiometric classification of hearing impairment: Recommendation 02/1 2003; BIAP.

13. Braschi E, Ross D, Korownyk C. Evaluating the Epley manoeuver. Can Fam Physician, 2015; 61(10): 878.

14. Balikci HH, Ozbay I. Effects of postural restriction after modified Epley maneuver on recurrence of benign paroxysmal positional vertigo. Auris Nasus Larynx, 2014; 41(5): 428-31.

15. Hughes D, Shakir A, Goggins S, Snow D. How many Epley manoeuvers are required to treat benign paroxysmal positional vertigo? JLO, 2015; 129(5): 421-24.

16. Brandt $\mathrm{T}$, Steddin S. Current view of the mechanism of benign paroxysmal positioning vertigo: Cupulolithiasis or canalolithiasis? J Vestibular Res, 1993; 3: 373-82.

17. Epley JM. Positional vertigo related to semicircular canalithiasis. Otolaryngol Head Neck Surg, 1995; 112: 154-61.

18. Pereira CB, Scaff M. Vertigem de posicionamento paroxistica benigna. Arq Neuro-Psiq, 2001; 59: 2B.

19. Babic BB, Jesic SD, Milovanovic JD et al. Unintentional conversion of benign paroxysmal positional vertigo caused by repositioning procedures for canalithiasis: Transitional BPPV. Eur Arch Otorhinolaryngol, 2014; 271: 967-73. 